\title{
Incorporating Traditional Knowledge in Environmental Impact Assessment- How Can It Be Done?
}

\section{Einar Eypórsson ${ }^{\star}$,}

Senior Researcher, High North Department, Norwegian Institute for Cultural Heritage

Research, Tromsø, Norway

Alma Elizabeth Thuestad,

Researcher, High North Department, Norwegian Institute for Cultural Heritage Research, Tromsø, Norway

\begin{abstract}
An obligation to consider traditional knowledge (TK) in planning, resource, and land management, particularly in Sami areas, has been formalized through the Nature Diversity Act. However, current Norwegian legislation and guidelines contain few clarifications of what TK is, how to approach it, or how to appropriately include such data in assessment and planning processes. The Norwegian Institute for Cultural Heritage Research has incorporated TK about land and resource use in several impact assessments (IAs), building on a methodological approach applied for a number of review assignments for the Finnmark Commission. While the experiences from reviews for the Commission and IAs concerning Sami land and resource use may represent a step towards incorporating TK in Norwegian planning processes, the approach to documentation, methodology, and ethics in this field is open for debate. The same can be said of the formal frameworks for IA and the willingness to incorporate $\mathrm{TK}$ in planning programs, in general.
\end{abstract}

Keywords: Sami traditional knowledge; land and resource use; impact assessment; Finnmark Commission

Received: April 2015; Accepted: June 2015; Published: November 2015

\section{Introduction}

In recent years, traditional knowledge (TK) has become increasingly recognized as a valuable source of information for planning and management of land and natural resources. Orally transmitted TK describing past and present land and resource use is now seen as relevant for scientific research, archeological surveying, land planning, resource management, impact assessments (IAs), and rights processes. ${ }^{1}$ An obligation to consider $\mathrm{TK}$ in planning, resource and land management, particularly in

^Correspondence to: Einar Eypórsson, Senior Researcher, High North Department, NIKU Nordområdeavdelingen, Framsenteret, postboks 6606 Langnes, NO-9296 Tromsø, Norway. Email: einar.eythorsson@niku.no 
Sami areas has been formalized through Section 8 of the Nature Diversity Act (NDA), ${ }^{2}$ which corresponds to Article 8 in the UN Convention on Biological Diversity. ${ }^{3}$ This obligation is further elaborated in guidelines worked out by the Sami Parliament (SP) $\left(2007^{4}, 2010^{5}\right)$. These guidelines are based on the 2006 Finnmark Act $(\mathrm{FA})^{6}$ and the 2008 Plan and Building Act (PBA). ${ }^{7}$ However, current legislation and guidelines contain few clarifications of what TK is, how to approach it, or how to appropriately include it in assessment and planning processes.

There is a growing interest in land and natural resources in northern Norway linked to mining projects, offshore oil and gas, wind power, salmon farming, tourism, and other industrial/commercial uses as well as a wide range of recreational activities. Proposed projects frequently involve conflicts with reindeer husbandry, farming, fishing, and other traditional uses. In many cases, development projects are also a potential threat to protected cultural heritage sites and environments, many of which reflect traditional land and resource use. Meanwhile, the Finnmark Commission (FC), established in 2008, is investigating potential customary property or use rights within the land areas managed by the Finnmark Estate Agency $\left(\mathrm{FeFo}^{8}\right)$. Mapping TK concerning historical land and resource use as well as customary rights based on oral sources plays a significant role in the expert reviews ${ }^{9}$ NIKU, in collaboration with other research institutes, ${ }^{10}$ has carried out for the FC in Finnmark pertaining to: 1) the islands Seiland and Stjernøya, 2) the municipality of Nesseby, 3) the island Sørøya, and 4) the municipality of Karasjok. These expert reviews have provided valuable experience and information from documentation and analysis of TK, which has been useful for the development of a methodological approach for incorporating TK in IAs.

IA is a mandatory element of planning processes preceding large-scale industrial or infrastructural projects. ${ }^{11}$ Article 1.1 of the SP's Planning Guidelines states that the objective is "to facilitate that all plans, impact assessments and resolutions, in accordance with the Plan and Building Act, safeguard the natural foundation for Sami culture, industries, and society."12 This article corresponds to Section 3-1c in the PBA. The PBA also grants the SP a right and an obligation to participate in planning processes within its field of operation, a practice which is in line with the administrative arrangements of other comparable government bodies. ${ }^{13}$ The inclusion of TK in IA processes is relevant for assessing potential impact from a wide range of development and planning projects. With reference to the PBA, the SP has on several occasions requested assessments of the impact of industrial projects on Sami (terrestrial and marine) resource use within the affected areas. These assessments are generally conducted separately from assessments of consequences for, for instance, reindeer herding and cultural heritage (Sami and other).

The Norwegian Institute for Cultural Heritage Research (NIKU) has carried out a number of IA assignments regarding potential consequences of planned projects for cultural heritage and few IAs concerning consequences for Sami settlement and resource use. The IA assignments and the FC expert reviews are separate processes, with different objectives and following different formal procedures. Nevertheless, since mapping of present and historical land and resource use is at issue in both 


\section{E. Eypórsson $\mathcal{E}$ A.E. Thuestad}

cases, the methodological challenges are somewhat similar. In this article, we address methodological, practical, and ethical challenges of approaching, collecting, and processing TK within the framework of such processes, and discuss whether the practices developed by NIKU represent a way towards implementation of the NDA Section 8, the PBA Section 3-1c and the SP guidelines. ${ }^{14}$ First, we introduce the concept of TK and its application within rights processes and planning in Norway and Canada. Then, we present a methodology applied by NIKU in FC reviews, and explain how its elements have been adapted for use in IAs. Finally, we discuss experiences from NIKU's attempts to integrate TK in IA assignments and ethical considerations related to them.

\section{The concept of TK}

A general obligation to include experience-based TK in planning and management of natural resources is clearly stated in the NDA Section 8:

[A] uthorities shall further emphasize knowledge based on the experience of generations, through use of and interaction with nature, including such use by the Sami, which can contribute to sustainable use and protection of biological diversity. ${ }^{15}$

The term TK is not applied directly in this paragraph; the emphasis is on knowledge derived from "use of and interaction with nature," and Sami knowledge is specifically mentioned. The relevance of knowledge that can contribute to sustainable use and protection of biological diversity is also underlined in the NDA. According to the White book accompanying the Act, this does not exclude experience-based knowledge concerning cultural heritage:

The term biological diversity can in itself build a bridge between protection of nature and protection of cultural heritage, since it includes culturally modified as well as wild biological diversity. ${ }^{16}$

Section 4 of the SP's guidelines for assessing Sami interests in cases of changing land use in Finnmark, ${ }^{17}$ with reference to NDA Section 8, states that "traditional practice and knowledge related to use of meahcci/outlying areas will be a central component of assessment."18 The SP's Planning Guidelines Article 4d also refers to this NDA Section 8 when stating that it is an obligation for all government bodies to apply TK in planning processes (within Sami settlement areas). ${ }^{19}$ None of these documents refer directly to "ecological knowledge," indicating that TK about cultural heritage, as well as TK about practices and customary rights related to land and natural resources is a part of what the Act's Section 8 describes as "knowledge based on the experience of generations, through use of and interaction with nature." Through the NDA, the concept of TK has become an integrated part of Norwegian legislation, but the law does not contain an operational definition of the concept, nor any further instructions on how it should be included in management and planning. This situation is not unique for Norway. Peter Usher ${ }^{20}$ has addressed a comparable lack of specific instructions about operating procedures on how to implement 
legal requirements to incorporate traditional ecological knowledge (TEK) in formal decision-making processes in Canada.

The term TK is frequently used interchangeably with TEK, indigenous knowledge (IK), local knowledge (LK), and local ecological knowledge (LEK). Berkes and Folke comment on the similarity of these terms:

The term indigenous knowledge (IK) is used to mean local knowledge held by indigenous peoples, or local knowledge unique to a given culture or society .... The term can be used interchangeably with traditional knowledge, but we prefer to use traditional ecological knowledge (TEK) more specifically to refer to a cumulative body of knowledge and beliefs, handed down through generations by cultural transmission, about the relationship of living beings (including humans) with one another and with their environment. ${ }^{21}$

In this definition of TEK, the word traditional refers to a temporal aspect of knowledge that has been "passed on from generation to generation." In policy documents, traditional (ecological) knowledge is often understood as a wide term, meaning ancient as well as contemporary knowledge derived from experience and interaction with nature and landscape. For consistency with the language of the quoted legal documents, we have applied the concept of TK in this study, while the knowledge we discuss can more precisely be understood as orally transmitted, experience-based LK that may or may not be characterized as ecological. While applied almost interchangeably with TK, the term LK has spatial connotations, referring to experience-based knowledge derived from practice within a given area or locality, regardless of whether it is handed down through generations or based on recent observations. ${ }^{22}$

Usher argues that all parties involved with IA processes need to know what TEK is, what information it can provide and how this information can be documented and brought into assessment processes. Usher's definition of TEK, similar to the definition used by Berkes and Folke, refers to "the environment," a term which includes culturally modified landscapes. Usher ${ }^{23}$ defines TEK as "all types of knowledge about the environment derived from the experience and traditions of a particular group of people," which can be classified into four categories: 1) knowledge about the environment, 2) knowledge about the use of the environment, 3) values about the environment, and 4) the knowledge system. A slightly modified version of Usher's categories $1-3$ is applied in a definition of TK in "Guidelines for incorporating traditional knowledge in environmental impact assessments," ${ }^{24}$ by the Mackenzie Valley Environmental Impact Review Board. These guidelines refer to TK (not TEK) as consisting of these categories:

1. Knowledge about the environment: This is factual or "rational" knowledge about the environment. It includes specific observations, knowledge of associations or patterns of biophysical, social and cultural phenomena, inferences, or statements about cause and effect, and impact predictions. All are based on direct observation and experience, shared information within the community and over generations. 


\section{E. Eypórsson $\mathcal{E}$ A.E. Thuestad}

2. Knowledge about use and management of the environment: This is the knowledge that people have about how they use the environment and how they manage their relationship with the environment. Examples include cultural practices and social activities, land-use patterns, archeological sites, harvesting practices, and harvesting levels, both past and current.

3. Values about the environment: This knowledge consists of peoples' values and preferences, what they consider "significant" or valued components of the environment, and what they feel is the "significance" of impacts on those valued components. Aboriginal spirituality and culture play a strong role in determining such values. This element of TK includes moral and ethical statements about the environment and about the relationships among humans, animals and the environment; the "right way" to do things.

The use of TK rather than TEK, the omission of the word "ecological" in TEK, can be interpreted to mean that TK about the environment is more than strictly ecological knowledge. Category 2 explicitly refers to cultural heritage: archeological sites, cultural practices, and land-use patterns. The guidelines also address ethical questions that are critical when incorporating TK in environmental assessment processes, especially the risk that TK may be taken out of context, regulated or appropriated by science or management institutions. This concern has been subject to debate among social scientists. Nadasdy $(2005)^{25}$ argues that adaptation of TK to bureaucratic structures does not serve to empower indigenous people, but rather to expand the reach of bureaucratic practices into indigenous communities. Without judging whether Usher's operationalization of TK contributes to empowerment or cooptation of indigenous people, we find the categories instrumental for the purpose of IAs.

\section{TK in the ongoing rights process in Finnmark}

\subsection{The Finnmark Commission}

Prior to 2006, 95\% of the surface area of Finnmark, covering $46,000 \mathrm{~km}^{2}$, was defined as state property. Following the implementation of FA Section 49, this area was transferred from the state-owned Statskog SF to FeFo. The FA, in Sections 5 and 29, stipulates the establishment of a commission tasked with determining the nature and scope of customary rights to land and natural resources acquired through prolonged use by Sami and other residents in Finnmark. Unlike other common lands in Norway, collective or private use or property rights established through prolonged use of land and natural resources have not been identified on previously state-owned land in Finnmark, and such rights issues were not resolved by transferring right of ownership from the state to FeFo. The FC was established with a mandate to investigate rights acquired not only by the Sami population, but also by Norwegians, Kvens, and other groups. ${ }^{26}$ In short, the procedure for rights investigation is that the FC makes a public announcement when a geographical area (felt) is opened for investigation and invites those who wish to claim customary property rights or use 
rights within the specified area to notify the Commission. All claims are made public through the FC website. ${ }^{27}$ Members and staff of the FC carry out their own investigations in addition to expert reviews carried out by independent reviewers. When an expert review is completed, it is made available through the FC website. Subsequently, a public hearing is arranged regarding the area being assessed before the FC concludes and writes its final report concerning the rights situation within that area. The FC has so far completed reports on four areas, ${ }^{28}$ all of which are available from the FC website. The conclusions drawn by the FC have status as court rulings; the rulings can be appealed to a special $\operatorname{court}^{29}$ and eventually to the Supreme Court.

The FC has, on several occasions, ${ }^{30}$ proclaimed competitions asking independent research institutes to submit proposals for expert reviews. Five area reviews ${ }^{31}$ describing historical and current use of specified areas have been completed, four of them carried out by NIKU. The review mandate is to identify land and resource user groups, and to describe the nature (content) of the use, its scope (extent), and its duration (permanence). The mandate thus encompasses a wide range of past and present land and resource uses within the review areas. It also includes spatial and temporal aspects of the uses, local peoples' perception of the rights situation and their responses to government regulations, past and present. ${ }^{32}$ In the tenders from NIKU to the FC, an orientation towards oral sources was underlined, without explicit reference to the concept of TK.

\subsection{Reviewing land-use practices for the FC}

Assorted written sources, various legal documents, and archival data provide an important basis of knowledge for the reviews. There are, however, few written sources that contain detailed information on Sami and other's historical land- and resourceuse practice. As the FC expert reviews are intended to cover past and present land and resource use, customary use rights and local management practices, TK obtained through oral sources, have been critical for completing the assignments. NIKU has approached the task through surveys and structured interviews with local residents, Sami and Norwegian. The choice of methodology used for the FC reviews was inspired by Canadian use and occupancy map surveys, as described by Terry Tobias, ${ }^{33}$ a method developed in collaboration with First Nations of Canada as a part of their struggle for recognition of land titles and resource rights. Tobias recommends that trained local interviewers conduct surveys, with technical support from research institutions. NIKU's emphasis in the review process has been on TK category $2,{ }^{34}$ knowledge about use and management of the environment, while category 1 , knowledge about the environment, has been a necessary part of the description of spatial and temporal characteristics of landscape and natural resources. Category 3, values about the environment, is not addressed directly, but it is expressed through quotations from transcribed interviews. 


\section{E. Eypórsson $\mathcal{E}$ A.E. Thuestad}

\subsection{The survey}

For areas 1-3, a map-based survey was distributed to all households. It consisted of a detailed questionnaire (in Norwegian and Sami) with maps attached, asking people to describe their families' land and resource uses, past and present, as well as their understanding of use rights or ownership of land and resources.

The survey questions referred to categories of land and resource use specifically mentioned in the FA. These were ordered into seven categories, referring to types of use mentioned in the FA:

1. Grazing areas for domestic animals (cows, goats, sheep, and horses) and outfields for hay production on common lands.

2. Grazing areas for reindeer, including fences, migration routes, and location of temporary residence for reindeer herders.

3. Fishing in rivers and lakes, and salmon fishing in the sea.

4. Hunting and trapping (grouse, moose, and other game).

5. Use of forests for firewood and building materials, location and use of peat fields.

6. Other forms of use, including berries, eggs and down, herbs, and so on.

7. Buildings, places of temporary residence, roads, and paths.

For each category, respondents were asked to name areas used by their families and demarcate them on the maps.

We received some feedback on the complexity of the survey questionnaire, including a formal letter from Forum for nature and outdoor recreation $(\mathrm{FNF})^{35}$ claiming that many people found it overwhelming and confusing. Despite the complexity of the survey, 102 completed forms from areas 1-3 were returned (Table 1).

More than $50 \%$ of the returned questionnaires were signed by men, aged 50 and above, but this does not necessarily mean that they only described use by male household members. The sample was certainly not representative of the population at large, considering age, gender, and occupation, but our priority was to gather a sample of knowledgeable persons. The quality and detail of the answers and mapmarkings is variable, but most respondents seemed painstakingly serious about getting the facts right.

Table 1. Number of survey responses and interviews in four completed area reviews

\begin{tabular}{lcc}
\hline Review areas & Number of responses to survey & Number of interviews \\
\hline Area 1: Seiland and Stjernøya & 22 & 28 \\
Area 2: Nesseby & 45 & 31 \\
Area 3: Sørøya & 35 & 33 \\
Area 4: Karasjok & 15 & 24 \\
\hline
\end{tabular}


The individual maps from the survey were processed in a Geographic Information System (GIS), ${ }^{36}$ resulting in a geodatabase organized according to the categories used in the questionnaire. The intention was to provide a digital database and a basis for using GIS as a tool for analyzing land and resource use, its scope, and duration. The actual implementation was, however, not without complications. The survey information reflects the level of accuracy provided by the answers to the questionnaire and demarcations on the attached maps. Another important factor influencing accuracy was our interpretation of answers, understanding the information provided was not necessarily straightforward. In some cases, map references and place names were unclear. Sami and Norwegian names were at times used indiscriminately; place names in Sami were spelled in a number of ways, and not always in accordance with the spelling occurring on official Norwegian maps. Since we were less familiar with the landscapes in question than the informants, we sometimes lacked sufficient background knowledge to understand references to locally used place names. The databases and the digital maps based on the survey data do represent useful indicators of the spatial distribution and density of land and resource use. However, to present them as accurate and representative information, valid as evidence in court, has proven problematic. Considering this limitation, as well as the high cost of distributing and processing the survey, we decided not to distribute the questionnaire and maps to all households in area 4 (Karasjok). This meant that less effort was put into producing a database and digital maps. The forms and maps developed for the survey were, however, made available ${ }^{37}$ to the public and they were still used in the interview setting.

Discontinuation of the household survey was mainly a question of efficient use of scarce resources. Despite a limited response, it had an important mission in distribution of information about the work of the FC and providing equal opportunity for all inhabitants to contribute.

\subsection{The interviews}

Survey respondents were asked if they were willing to give an interview as a followup. Roughly $50 \%$ confirmed and were later contacted for interviews. Half of the sample of interviews was people who had not responded to the survey, selected in order to balance the sample in terms of geography and economic adaptation. In the first two reviews, the interviews were semi-structured, but later they became more structured, following the setup of the questionnaire. All interviews were taped and transcribed; transcriptions were sent to the interviewees to be signed for approval. In area 4 (Karasjok), all interviews were conducted by SEG, a local partner institution ${ }^{38}$ with personnel fluent in the Sami and Finnish languages. For interviews and survey alike, all informants signed a form of informed consent, accepting that their identity would be known to the FC but anonymized in the published version of the report.

Compared to the survey, the information from interviews was easier to interpret and apply in the review text. The risk of misinterpretation appeared to be lower when interviews were carried out by persons familiar with the local culture and fluent in Sami as well as the Norwegian language. Informants could be asked to clarify unclear 


\section{E. Eypórsson $\mathcal{E}$ A.E. Thuestad}

statements directly during the interview, and at a later stage, they could control transcriptions for misunderstandings or errors.

\subsection{TK in impact assessments}

In recent years, NIKU has carried out a number of IAs with the intention of meeting the obligation to include TK as spelled out in the SP guidelines, an intention that has been made explicit in NIKU's tenders for these IA assignments. Some of these IAs are focused on impacts of industrial projects and infrastructure on cultural heritage (Sami and non-Sami), while others are concerned with impact on Sami land and resource use. In both cases - particularly for IAs on Sami land and resource use - all three categories of $\mathrm{TK}^{39}$ are relevant: knowledge 1) about the environment, 2) about use and management of the environment, and 3) values about the environment.

In general, formal requirements in the structure of IAs, combined with time constraints and tight budgets, limit the opportunities for TK documentation through interviews or surveys, but within the IA framework, NIKU has applied elements from the FC review methodology to address Sami land-use practices.

\subsection{Frameworks for IA}

In Norway, the term IA is used to describe both the process and the result. Starting with for example, public notification of intent, public hearings, and preparation of planning documents, the IA process encompasses a systematic mapping of the expected consequences of a development or planning initiative. The term is also used to describe the thematic and final reports outlining assessments of consequences. IAs are intended to ensure that knowledge regarding impact on environmental and societal interests is integrated in all phases of planning and development issues, thereby providing a sound base of knowledge for the decision-making process. ${ }^{40}$ Furthermore, they are intended to ensure broad participation of affected stakeholders such as NGOs, citizens, and public bodies. IA is today incorporated in a complex regime of legal demands and provisions determined by laws and regulations as well as EU directives. ${ }^{41}$

The PBA Section 14, which contains legislation on IA, is accompanied by Regulations on environmental plans for the Planning and Building Act (RPBA) ${ }^{42}$ The RPBA expands on the requirements of the PBA and contains the actual regulations that determine which development or planning initiatives trigger IAs. The RPBA also regulates the IA process and the contents of an IA report. The regulations encompass fairly detailed demands regarding for example, biodiversity, cultural heritage sites and environments, landscape, Sami interests, and other interests in outlying areas. RPBA, Appendix III, states that an IA should provide a description and assessment of the impacts an initiative may have on environmental and societal interests, referring to for example, cultural heritage sites and environments, biodiversity, landscape considerations, safeguarding arable land, and Sami cultural and natural foundations. ${ }^{43}$

Methodological approaches as well as the contents of an IA report are additionally regulated by thematic guidelines such as the previously mentioned SP guidelines. ${ }^{44}$ 
Section 2 of these guidelines provides a clarification of the term outlying areas (in Sami: meahcci) and describes and exemplifies various forms of land and resource use that are encompassed by the term traditional Sami use of outlying areas. According to Section 3, assessment of changes in use of outlying areas should be based on customary use and whether such use can be continued as before.

Guidelines for evaluating cultural heritage sites and environments in an IA process ${ }^{45}$ have been developed by the Directorate for Cultural Heritage (DCH). ${ }^{46}$ The aim ${ }^{47}$ of these guidelines is to improve the quality of IA reports, to ensure that cultural heritage is considered throughout the IA process and, finally, that IAs are coordinated with the requirements of the Cultural Heritage Act (CHA). ${ }^{48}$ The terms cultural heritage site and cultural heritage environment are defined with reference to the $\mathrm{CHA}^{49}$ and the guidelines go on to describe both the process and what an IA report regarding cultural heritage should contain. Value assessment of cultural heritage is considered an important part of the process and, consequently, a set of criteria for assessing the value of cultural heritage sites and environments is outlined. Ascribed value is an important means for prioritizing cultural heritage assets, and IAs should evaluate how cultural heritage assets within an area will be affected and changed by a planned project and how these changes affect the value of the cultural heritage.

In addition to thematic guidelines, guidelines primarily focusing on the methodological approach have been developed. Although developed by the Norwegian Public Roads Administration for use in road projects, the methodological approach outlined in Guidelines $140^{50}$ and the revised version, V712, ${ }^{51}$ is in widespread use for evaluating potential consequences of a wide range of development and planning projects.

The DCH guidelines predate the SP guidelines and do suggest TK as a viable source of information. However, it is primarily in more recent years a number of archeological surveys triggered by various development projects or plans have mapped and utilized TK. ${ }^{52}$ Neither the 140 nor the recently published V712 Guidelines deal with TK or assessment of consequences for Sami land and resource use.

NIKU has conducted several IAs based on the SP guidelines (2007) regarding proposed projects in Finnmark. The planning documents generally specify which methodological approach is to be used in any given assessment. As V712 does not specifically deal with TK and traditional Sami landscapes, NIKU has adapted the methodological approach outlined in the SP guidelines to the general IA framework. IAs are generally to be based on existing knowledge, but where current knowledge is insufficient, additional data can be gathered. In most cases, previous documentation of TK is limited, and some data collection as a part of the IA is often necessary. The examples below describe how this has been done in specific cases.

\subsection{Reopening of a copper mine in Repparfjord}

In 2011, NIKU conducted an IA regarding "coastal Sami use of the fjord and coast" as a part of the planning process for reopening a copper mine in Repparfjord in Kvalsund municipality, Finnmark. The IA report ${ }^{53}$ refers to the SP guidelines ${ }^{54}$ 


\section{E. Eypórsson $\mathcal{E}$ A.E. Thuestad}

on the obligations to incorporate TK, and four interviews with local fishermen were carried out as a part of the assessment. A local interviewer conducted and transcribed the interviews. The information derived from the interviews, including a map showing the location of areas in use for fishing and fish farming, amounts to eight of the report's 37 pages. The informants are presented with their full name and a short biography of their fishing career in Repparfjord. The data from the interviews are presented in five subchapters:

1. Fishing in Repparfjord in the 20th Century

2. Ecological conditions, fish species, and spawning areas

3. Salmon fishing and salmon farming

4. Copper mining in 1972-1978 and its impact on the fisheries in the fjord

5. The present situation-considering the planned reopening of the mine

The three categories of TK are all represented in the text. Knowledge about the environment (category 1) is presented in Chapter 2, where the informants describe the ecological conditions and how these have changed during their fishing career. It is important to note that since very little biological data are available on the ecology of Repparfjord in a long-term perspective, TK was almost the only available source. The main bulk of the text in Chapters 1,3 , and 4 is concerned with knowledge about use and management of the environment (category 2). These chapters describe historical changes in the fisheries and the informants' experiences with copper mining in the fjord in the 1970s. Values about the environment (category 3) are also represented throughout the text, especially in Chapter 5, for instance where one informant gives this statement on the mining plans, which include placement of mine tailings in the sea: The fjord has always been the heart of this community; the fishery was the reason we chose to settle here. It is a shame that the fjord will once again be neglected and raped, because of the copper mine. ${ }^{55}$

\subsection{Oil terminal at Veidnes}

NIKU has conducted IAs regarding possible consequences of a planned oil terminal at Veidnes in Nordkapp municipality in Finnmark for three distinct themes: Sami traditional land and resource use, ${ }^{56}$ Sea-Sami fisheries ${ }^{57}$, and cultural heritage sites and environments. ${ }^{58}$ The cultural heritage reports are primarily based on the existing literature and cultural heritage databases, ${ }^{59}$ and were executed according to the methodology outlined in V712. The planning documents ${ }^{60}$ for the Johan Castberg oil terminal specifically mention Sami land and resource use, and they clearly state that consequences for Sami traditional industries, including Sea-Sami fisheries, shall be included in the IA process. As for the other reports, the methodology was to follow V712, but it was necessary to adapt the criteria listed in the guidelines prior to the assessment. A large portion of the reports focusing on traditional use are dedicated to historical accounts about Sami use of land and resources and Sea-Sami fisheries, respectively. A total of five informants were interviewed for both reports. The interviews were structured map-based interviews focusing on information 
regarding scale and duration of the interviewees' traditional use. The uses were ascribed to six main categories defined in accordance with SP guidelines Section 6 and FA Section 22-Section 23, duration and scale were noted, and resource areas were mapped. Of the three categories of TK, the focus is on knowledge about the environment (category 1) and knowledge about use and management of the environment (category 2), but aspects regarding values about the environment (category 3 ) are also intermittently present in the text.

\subsection{Harbor and infrastructure at Tømmernes in Sør-Varanger}

NIKU's assignment ${ }^{61}$ in 2014 was to assess potential impacts of a planned industrial harbor and infrastructure at Tømmernes, close to Kirkenes, for "Sami settlements, land use and marine salmon fishery." A separate IA on the subject was a request of the SP. A letter from the SP spelled out that the assessment should be based upon $\mathrm{TK}$, as well as scientific data and information from management agencies.

TK documentation for this assignment consisted of interviews with six informants originating from different parts of the plan area. The themes covered were mainly history and economic adaptation of the Sami settlements, as well as past and present land and resource use by the Sami population in the area. The interviews were carried out by the project leader and were structured similarly to the interviews for the FC reviews. The text derived from interviews covers 11 out of 58 total pages, including a map of Sami settlements in the area. The main bulk of the text can be characterized as TK about use and management of the environment (category 2) and category 1, knowledge about the environment. Category 3, values about the environment, is less pronounced in the report.

\subsection{Documentation of TK for IA-how can it be done?}

The brief case descriptions above demonstrate how NIKU has attempted to incorporate traditional land and resource use in IAs. The methodological approach applied for FC reviews and the experiences from FC assignments has been quite useful for IA assignments. As the subject matter of the IAs in question is past and present land and resource use by the Sami, the categories applied in FC reviews are also applicable in the IAs. The economic and formal frameworks for IAs strictly limit the opportunity for TK documentation and mapping in the field. Considering the TK categories suggested by Usher and applied by the Mackenzie Valley Environmental Impact Review Board, the main bulk of TK data collected in the IA processes are category 1 , knowledge about the environment, and category 2, knowledge about use and management of the environment. Values about the environment (category 3 ) and ethical considerations related to TK in IAs are only briefly discussed in these IA reports. However, these cases show that it is possible within the current frameworks to include a certain degree of TK documentation in IAs, especially IAs on Sami land and resource use. It is legitimate to ask whether this documentation is good enough, representative enough, or methodologically and ethically acceptable. It has been necessary to strike a balance between what is feasible within the prevailing constraints in 


\section{E. Eypórsson $\mathcal{E}$ A.E. Thuestad}

the current IA system and an ideal situation where documentation of TK would be recognized as a necessary element of IA.

In this study, we have adhered to Usher's operational definition of TK for the purpose of environmental IAs with a focus on documentation of past and present land and resource use. We have chosen not to engage in academic discussions about definitions and multi-faceted contents of TK and related concepts. ${ }^{62}$ Our methodology has been oriented towards oral sources, influenced by Canadian land use and occupancy mapping. The IA assignments quoted above represent attempts to put the obligation to incorporate TK, as stated in the SP planning guidelines, into practice. Ellis $(2005)^{63}$ notes that obligations to incorporate TK in environmental decision making may be characterized as a "top-down" approach, as structures of governance are constructed to accommodate TK while the knowledge itself is not fostered or sought out. We are aware of the risks of appropriation and adaptation of TK to bureaucratic structures and the power exercised by scientists and managers who define what TK is, which of its elements are relevant and how it can be documented appropriately. Incorporation of TK in environmental decision-making is not a straightforward exercise. Our position as practitioners in the trade of IAs is that we cannot ignore the established legal obligation to include TK and that we need to continue our efforts to develop proper ways to do that in a responsible manner.

\section{Ethical considerations}

Certain ethical questions arise as TK becomes recognized as a legitimate source of information in planning and rights assessments, particularly in Sami areas. There are questions regarding ownership and control of $\mathrm{TK},{ }^{64}$ who is in a position to represent it correctly and how it should be disseminated and stored. There are also concerns about the risk that TK will be taken out of context and appropriated by science and planners. It is sometimes relevant to ask whether it is in the interest of local people to reveal details of their past and present land and resource use; for instance specified information describing where they go fishing, hunting, and picking cloudberries. These activities were economically significant for many households until only a few decades ago. Today, although still a supplement to the household, these activities are primarily continued as recreation and maintenance of family traditions. At present, access to these resources is more or less open. When spatial information about traditional land use and resource harvesting becomes available online, as in the case of FC reviews, there can be a risk of exploitation of the information in ways not originally intended. On the other hand, the objective of use and occupancy mapping for FC reviews and IAs is to inform decision-makers about possible customary rights as well as natural and cultural values in environments that will be affected by planned actions. Keeping these secret in such settings may not be the best strategy for defending them. In certain cases however, the possibility of revealing potentially sensitive information without risking it becoming public knowledge, is of great importance. 
Publication of digital maps for FC reviews may represent this dilemma: The maps are merely aggregated representations of how the participating informants have marked the spatial distribution of their own or their families' use of land and natural resources, ${ }^{65}$ without any form of authoritative verification. As such, the maps may realistically be of little consequence as evidence for specific land claims. Map layers are used as illustrations to the text, to demonstrate spatial patterns of different kinds of use, past and present; they visualize how different user groups identify their traditional areas, as overlapping layers on a map. The visualization itself may potentially alter how these landscapes are evaluated in planning and IAs. This dilemma is closely related to the question of reliability of TK, and how orally transmitted information can be verified before it is translated into map layers.

The concepts of value and assessment of value are an integral part of IAs. As such, what is considered valuable and the criteria used for assessing value are of importance. Within the framework of an IA process, knowledge acquisition can be considered as a social process where different norms, values, and interests affect what is perceived as good and relevant knowledge on which to base decisions. ${ }^{66}$ By incorporating $\mathrm{TK}$, category 3, values about the environment, value elements that would otherwise not be heard in decision-making processes, could be explicitly expressed.

\section{Concluding remarks}

We have substantiated that an obligation to include TK in planning processes, IAs in particular, is currently a part of Norwegian legislation. The Sami Parliament's Planning Guidelines underline the relevance of this obligation for the Sami people, but there is no reason to believe that the relevance of TK applies exclusively to planning in regions with a Sami population. This fact is yet to be reflected in general guidelines on IA in Norway. Traditional use of land and resources has recently been a theme in several IA processes in north Norway; the SP guidelines have played a pivotal role in this development. Even though TK is now recognized as valuable in several fields, in a recent publication ${ }^{67}$ focusing on IAs in Norway there is no mention of TK or traditional land and resource use as a part of the IA process. Nor is this specifically mentioned in the V712. The SP Planning Guidelines are explicit on the obligation to integrate TK in planning, but contain few clues on how this should be done. A similar challenge from a Canadian context is addressed by Peter J. Usher. ${ }^{68}$ The Mackenzie Valley Environmental Impact Review Board has worked out operational guidelines for incorporating TK in IAs, which could serve as a model for Norwegian guidelines on the issue.

While the experiences from reviews for the FC and IAs about Sami land and resource use may represent a step towards incorporating TK in Norwegian planning processes, the approach to documentation, methodology and ethics in this field is open for debate. The same can be said of the formal frameworks for IA and accommodating TK in planning programs in general. 


\section{NOTES}

1. See, for example, Falch, Torvald, and Marianne Skandfer. "Sámi Cultural Heritage in Norway: Between Politics of Local Knowledge and the Power of the State," In Northern Ethnographic Landscapes. Perspectives from Circumpolar Nations, eds. Igor Krupnik, Rachel Mason, and Tonia W. Horton, 356-375. Washington, DC: Arctic Studies Center, National Museum of Natural History, Smithsonian Institution, 2004; Eythorsson, Einar. Sjøsamene og kampen om fjordressursene [The Coastal Sami and the struggle for the fjord resources]. KáráŠjohka-Karasjok: ČálliidLágádus, 2008; Brattland, Camilla. "Mapping Rights in Coastal Sami Seascapes," Arctic Review on Law and Politics no. 1 (2010): 28-53; Riseth, Jan Åge, et al. "Sámi Traditional Egocological Knowledge as a Guide to Science: Snow Ice and Reindeer Pasture Facing Climate Change," Polar Record 47, no. 242 (2010): 202-17; Barlindhaug, Stine. "Cultural Sites, Traditional Knowledge and Participatory Mapping. Long-Term Land Use in a Sámi Community in Coastal Norway," In Dissertation for the degree of Philosophiae Doctor. Tromsø: University of Tromsø, Department of Archaeology and Social Anthropology, 2013.

2. LOV-2009-06-19-100: Lov om forvaltning av naturens mangfold (naturmangfoldloven) [Nature Diversity Act].

3. Convention on Biological Diversity, http://www.cbd.int/convention/text/default.shtml (accessed January 16, 2015).

4. Sametingets retningslinjer for vurderingen av samiske hensyn ved endret bruk av meahcci/ utmark i Finnmark (Guidelines for Assessment of Sami interests in cases of changes in land use in Finnmark), 2007. The status of the Guidelines as injunction to the FA was approved by the Norwegian government in 2007 . The guidelines are available from https:/lovdata.no/ dokument/SF/forskrift/2007-06-11-738 (accessed February 4, 2015).

5. Sametingets planveileder. Veileder for sikring av naturgrunnlaget for samisk kultur, næringsutøvelse og samfunnsliv ved planlegging etter plan- og bygningsloven (plandelen) (The Sami Parliament's Planning Guidelines), 2010. http://www.sametinget.no/Miljoe-areal-ogkulturvern/Areal/Sametinget-planveileder/Sametinget-planveileder (accessed September 7, 2015).

6. LOV-2005-06-17-85: Lov om rettsforhold og forvaltning av grunn og naturressurser i Finnmark fylke (finnmarksloven) [Finnmark Act].

7. LOV-2008-06-27-71: Lov om planlegging og byggesaksbehandling (plan- og bygningsloven) [Plan and Building Act].

8. FeFo (Finnmarkseiendommen) is an independent legal entity and currently manages land and natural resources on all former state-owned land in accordance with the purpose and provision of the Finnmark Act on behalf of the county's residents.

9. All reviews are available from http://www.domstol.no/no/Enkelt-domstol/Finnmarkskommisjonen/ Dokumenter/Sakkyndige-utredninger/ (accessed January 5, 2015).

10. The FC reviews were carried out by NIKU in collaboration with University of Tromsø, Northern Research Institute (Norut) and Sami Trade and Development Centre (SEG).

11. Plan- og bygningsloven [Plan and Building Act].

12. Original text: "Planveilederens formål er å legge til rette for at alle planer, konsekvensutredninger og vedtak som følger plan- og bygningslovens plandel sikrer naturgrunnlaget for samisk kultur, næringsutøvelse og samfunnsliv," Sametingets planveileder (The Sami Parliament's Planning Guidelines), 2010.

13. The Sami Parliament's Planning Guidelines, section 3-2. "Alle offentlige organer har rett og plikt til å delta i planleggingen når den berører deres saksfelt eller deres egne planer og vedtak og skal gi planleggingsmyndighetene informasjon som kan ha betydning for planleggingen. Dette gjelder også for Sametinget.”

14. 2007, 2010. 
15. This paragraph is based on Article 8 (j) of the UN Convention on Biological Diversity: Subject to its national legislation, respect, preserve and maintain knowledge, innovations and practices of indigenous and local communities embodying traditional lifestyles relevant for the conservation and sustainable use of biological diversity and promote their wider application with the approval and involvement of the holders of such knowledge, innovations and practices and encourage the equitable sharing of the benefits arising from the utilization of such knowledge, innovations and practices.

16. NOU 2004:28 Lov om bevaring av natur, landskap og biologisk mangfold-Naturmangfoldloven, chapter 20.2.1.

17. 2007.

18. Original text: "Det planlagte tiltaket må vurderes opp mot den bruken samiske utmarksbrukere har av det aktuelle området, og de konsekvensene det vil få for denne bruken. Tradisjonell praksis og kunnskaper knyttet til bruken av meahcci/utmark vil være en sentral del av grunnlaget for vurderingen."

19. Sametingets planveileder (The Sami Parliament's Planning Guidelines), 2010. Original text: "Prinsipper for statlige, regionale og kommunale organer som utarbeider planstrategier, planer, fastsetter utredningsprogram og fatter vedtak etter plan- og bygningslovens plandel, samt behandler konsesjonssaker er å: ....(d) legge tradisjonell kunnskap om og bruk av området til grunn for utforming av planer."

20. Usher, Peter J. "Traditional Ecological Knowledge in Environmental Assessment and Management," Arctic 53, no. 2 (2000): 183-93.

21. Berkes, F., and C. Folke, eds., Linking Social and Ecological Systems. Management Practices and Social Mechanisms for Building Resilience. Cambridge: Cambridge University Press, 1998, 5.

22. Eythórsson, Einar, and Camilla Brattland. "New Challenges to Research on Local Ecological Knowledge: Cross-Disciplinarity and Partnership" in Fishing People of the North. Cultures, Economies and Management Responding to Change. Fairbanks, Alaska: Alaska Sea Grant, 2012, 131-52.

23. Usher, "Traditional Ecological Knowledge."

24. Mackenzie Valley Environmental Impact Review Board, Guidelines for incorporating Traditional Knowledge in Environmental Impact Assessment, 2005, http://www.reviewboard.ca/ upload/ref_library/1247177561_MVReviewBoard_Traditional_Knowledge_Guidelines.pdf (accessed March 18, 2015); and A description of the development of the guidelines is available from http://www.reviewboard.ca/upload/ref_library/352_Schuh_Guidelines_for_ Incorporating_Traditional_Knowledge_into_the_EIA_1184018866.PDF (accessed March 18, 2015).

25. Nadasdy, Paul. "The Anti-Politics of TEK: The Institutionalization of Co-management Discourse and Practice" Athropologica 47 (2005): 215-32.

26. The Commission is also intended to contribute towards fulfilling Norway's obligations under ILO Convention No. 169, Article 14.2: “Governments shall take steps as necessary to identify the lands which the peoples concerned traditionally occupy, and to guarantee effective protection of their rights of ownership and possession."

27. The Finnmark Commission. http://www.domstol.no/no/Enkelt-domstol/Finnmarkskommisjonen/ (accessed September 7, 2015).

28. Area 1 Stjernøya/Seiland, Area 2 Nesseby, Area 3 Sørøya and Area 5 Varangerhalvøya øst.

29. Utmarksdomstolen for Finnmark.

30. The first round of reviews covering areas 1 and 2 was announced in 2009, area 3 was announced in 2010, areas 4 and 5 in 2011, area 6 in 2013 and the, for the time being, last review of area 7 was announced in 2014.

31. Eypórsson, Einar, Myrvoll, Elin Rose, Myrvoll, Marit, Thuestad, Alma, Bjerkli, Bjørn, Evjen, Bjørg, Joks, Solveig and Ravna, Øyvind, Felt 1. Stierdná/Stjernøya og Sievju/Seiland. Sakkyndig utredning for Finnmarkskommisjonen. NIKU Oppdragsrapport 42/2011, Oslo 
2011; Eybórsson, Einar, Myrvoll, Elin Rose, Myrvoll, Marit, Thuestad, Alma, Bjerkli, Bjørn, Evjen, Bjørg, Joks, Solveig and Ravna, Øyvind, Felt 2. Unjárgga gielda/Nesseby kommune. Sakkyndig utredning for Finnmarkskommisjonen. NIKU Oppdragsrapport 43/ 2011, Oslo 2011; Myrvoll, Marit, Eythórsson, Einar, Thuestad, Alma, Bjerkli, Bjørn, Dahlsbø, Elisabeth T., Evjen, Bjørg, Eira, Rávdna Biret Marjá and Ravna, Øyvind. Felt 3 Sállan/Sørøya. Sakkyndig utredning for Finnmarkskommisjonen. NIKU Oppdragsrapport 241/2011, Oslo 2011; Myrvoll, Marit, Riseth, Jan Åge, Thuestad, Alma, Evjen, Bjørg, Dahlsbø, Elisabeth T. and Samuelsen, Trine, Felt 4 Karasjok. Sakkyndig utredning for Finnmarkskommisjonen. NIKU Oppdragsrapport 10/2013, Oslo 2013; Øian, Hogne, Skår, Margrete, Aas, Øystein, Andersen, Oddgeir and Eira, Lájlá Helene, Felt 5-Varangerhalvøya øst. Sakkyndig utredning for Finnmarkskommisjonen. NINA Rapport 881, Lillehammer 2012.

32. "[The review should provide] a descriptive account of how different groups (farmers, reindeer herders, coastal and fjord fishers, salmon (sea) fishers, mixed economy households, permanent residents, recreational user/the general public and others) have used land and natural resources in the review areas. The nature and scope of the use and its duration must be described. It is important to focus on historical use as well as current use. Common understandings of the rights situation related to land and resource use, past and present, should be described. It is also of interest to investigate how land/resource use and understandings of the rights situation have evolved, and how the local population and other user groups have responded to state regulations since the 1775 Royal Decree on tenure on state lands in Finnmark" [own translation].

33. Terry N. Tobias. Tobias, Terry, Living Proof. The Essential Data-Collection Guide for Indigenous Use- and Occupancy Map Surveys. Vancouver, BC: Ecotrust Canada \& Union of British Columbia Indian Chiefs, 2009.

34. Mackenzie Valley Review Board 2005.

35. Forum for natur og friluftsliv.

36. ESRI $^{\circledR} \operatorname{ArcMap}^{\mathrm{TM}} 9.3$.

37. Questionnaires and maps were available at the Karasjok town hall and through NIKU's website.

38. Sami Trade and Development Centre (SEG) in Tana.

39. Mackenzie Valley Review Board 2005.

40. Holth, Fredrik, and Nikolai K. Vinge, eds., Konsekvensutredninger. Rettsregler, praksis og samfunnsvirkninger [Impact Assessments, Law, Practice and Social Impact]. Universitetsforlaget, 2014; Tesli, Arne, Jørn Thomassen, and Jan Sørensen, eds., Kvaliteten på norske konsekvensutredninger. Gjennomgang, kvalitetsvurdering og metodeutvikling, Samarbeidsrapport [The Quality of Norwegian Impact Assessments]. Oslo: NIBR/Miljøalliansen, 2006.

41. Holth and Vinge, Konsekvensutredninger.

42. FOR-2014-12-19-1726: Forskrift om konsekvensutredninger for planer etter plan- og bygningsloven.

43. Forskrift om konsekvensutredninger for planer etter plan- og bygningsloven.

44. 2007.

45. Anonymous. Kulturminne og kulturmiljø $i$ konsekvensutgreïngar. Rettleiar [Cultural Heritage and Cultural Environments in Impact Assessments. Guidelines]. Oslo: Riksantikvaren (Directorate for Cultural Heritage), 2003.

46. The Directorate for Cultural Heritage (Riksantikvaren) is responsible for the management of archeological and architectural monuments, sites and cultural environments in accordance with relevant legislation.

47. Anonymous. Kulturminne og kulturmiljø, 3.

48. LOV-1978-06-09-50: Lov om kulturminner (kulturminneloven) [Cultural Heritage Act]. 
49. Med kulturminner menes alle spor etter menneskelig virksomhet i vårt fysiske miljø, herunder lokaliteter det kytter seg historiske hendelser, tro eller tradisjon til. Med kulturmiljøer medes områder hvor kulturminner inngår som del av en større helhet eller sammenheng. Kulturminneloven $₫ 2$.

50. Anonymous. Konsekvensanalyser. Håndbok 140 [Impact Assessments. Handbook 140]. Oslo: Statens vegvesen (Norwegian Public Roads Administration), 2006.

51. Anonymous. Konsekvensanalyser. Håndbok V712 [Impact Assessments. Handbook V712]. Oslo: Statens vegvesen (Norwegian Public Roads Administration), 2014.

52. See e.g. Barlindhaug, Stine, Thomas Risan, and Alma Thuestad. Kulturhistoriske registreringer. Porsangermoen - Hálkavárri skytefelt [Registrations of Cultural History at PorsangermoenHálkavárre Military Training Field]. NIKU Rapport 17, Oslo, 2007; Schanche, Kjersti. Registrering av samiske kulturminner i forbindelse med 420 kV-ledning BalsfjordHammerfest. Oppsummering av feltsesongen 2010 og identifisering av konfliktområder [Registration of Sami Cultural Heritage related to a 420 kiloVolt power line from Balsfjord to Hammerfest. Summary of the field season 2010 and identification of conflict areas]. Karasjok: Sametinget (The Sami Parliament), 2011.

53. Eythórsson, Einar. Konsekvenser for sjøsamisk bruk av Repparfjorden og sjøncere arealer. Konsekvensutredning for planlagt gruvedrift $i$ Nussir og Ulveryggen $i$ Kvalsund kommune [Consequences for Coastal Sami use of Repparfjord, sea and coastal areas. Impact Assessment for planned mining operation at Nussir and Ulveryggen in Kvalsund Municipality]. NIKU Oppdragsrapport 70/2011, Tromsø, 2011, http://www.nussir.no/ environmental-pub/esia/NIKU Seasami ESIA Study N 30mar11.pdf (accessed March 10, 2015).

54. 2007, 2010.

55. Eythórsson, Konsekvenser for sjøsamisk bruk av Repparfjorden og sjøncere arealer.

56. Brattland, Camilla. Fohan Castberg; Landterminal Veidnes, Nordkapp kommune. Forelopig konsekvensutredning for samisk utmarksbruk og nceringer [Johan Castberg; Land-based Terminal at Veidnes, Nordkapp Municipality. Preliminary Impact Assessment for Sami Land use and Sami Industries]. NIKU Oppdragsrapport 50/2015, Oslo, 2015.

57. Brattland, Camilla. Fohan Castberg; Landterminal Veidnes, Nordkapp kommune. Forelopig konsekvensutredning for sjøsamisk fiske [Johan Castberg; Land-based Terminal at Veidnes, Nordkapp Municipality. Preliminary Impact Assessment for Coastal Sami Fisheries]. NIKU Oppdragsrapport 54/2015, Oslo, 2015.

58. Os, Kristin and Elin Rose Myrvoll. Johan Castberg; Landterminal Veidnes, Nordkapp kommune. Foreløpig konsekvensutredning for kulturminner og kulturmiljø [Johan Castberg; Land-based terminal at Veidnes, Nordkapp Municipality. Preliminary Impact Assessment for Cultural Heritage and Cultural Environment]. NIKU Oppdragsrapport 30/2015, Oslo, 2015; Barlindhaug, Stine. Fohan Castberg; Konsekvensutredning for deltema marine kulturminner [Johan Castberg; Impact Assessment for Marine Cultural Heritage]. NIKU Oppdragsrapport 107/2013, Oslo, 2013.

59. Askeladden. National Database for Protected Cultural Heritage in Norway. http://www. riksantikvaren.no/Veiledning/Data-og-tjenester/Askeladden (accessed September 7, 2015).

60. Anonymous. Skrugard Onshore Terminal; Plan og tredningsprogram [Skrugard Onshore Terminal; Plan and Assessment Program]. Tromsø: Multiconsult, 2013.

61. Eythórsson, Einar, Kommunedelplan for Tømmernes $i$ Sør-Varanger kommune. Konsekvensutredning for samisk bosetting, utmarksbruk og sjølaksefiske [Municipality Plan for Tømmernes in Sør-Varanger Municipality. Impact Assessment for Sami Settlement, Land-use and seasalmon fishery]. NIKU oppdragsrapport 143/2014, Oslo, 2014.

62. Davis, Anthony, and Kenneth Ruddle. "Constructing Confidence: Rational Scepticism and Systematic Enquiry in Local Ecological Knowledge Research,” Ecological Applications 20, no. 3 (2010): 880-94. 
63. Ellis, Stephen. "Meaningful Consideration? A Review of Traditional Knowledge in Environmental Decision Making," Arctic 58, no 1 (2005): 66-77.

64. Solbakk J. T., ed., Traditional Knowledge and Copyright. Sámikopiija, Karasjok, 2007.

65. Eythórsson, Felt 1. Stierdná/Stjernøya og Sievju/Seiland, 7; Eythórsson, Felt 2. Unjárgga gielda/ Nesseby kommune, 7; Myrvoll, Felt 3 Sállan/Sørøya, 22; and Myrvoll, Sakkyndig utredning for Finnmarkskommisjonen, 177.

66. Holth and Vinge, Konsekvensutredninger, 165.

67. Holth and Vinge, Konsekvensutredninger.

68. Usher, "Traditional Ecological Knowledge." 